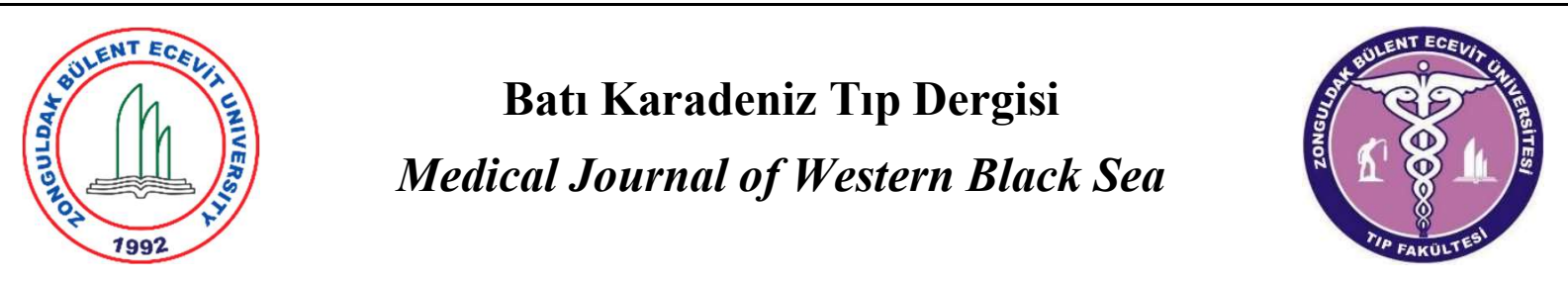

Araştırma Makalesi

Doi: 10.29058/mjwbs.2019.2.1

\title{
Kalıcı Saat Uygulamasının Üniversite Öğrencilerinin Günlük Yaşantısına Ve Uyku Düzenlerine Etkisi
}

Hazal Kardelen Kahraman a , Gaye Atmaca a, Güliz Gülün ${ }^{\text {a }}$, Hasbiye Çalişkanª İpek Örenbaş a, İrem Tokel $^{\text {a }}$, Melike Saridoğan ${ }^{\text {a, }}$, Mustafa Çağatay Büyükuysal ${ }^{b}$, Zehra Safi Ö $z^{c}$

${ }^{a}$ Zonguldak Bülent Ecevit Üniversitesi Tıp Fakültesi Dönem 4 Öğrencileri, Zonguldak, Türkiye.

${ }^{b}$ Zonguldak Bülent Ecevit Üniversitesi Tıp Fakültesi, Biyoistatistik Anabilim Dalı, Zonguldak, Türkiye.

${ }^{\mathrm{c}}$ Zonguldak Bülent Ecevit Üniversitesi Tıp Fakültesi Tıbbi Biyoloji Anabilim Dalı, Zonguldak, Türkiye.

ORCID : Hazal Kardelen Kahraman 000000029713 2733, Gaye Atmaca 000000033527 0767, Güliz Gülün 000000027638 7796, Hasbiye Çalişkan 000000018430 4041, İpek Örenbaş 000000018044 5816, İrem Tokel 000000027239 2993, Melike Saridoğan 000000031589 6658, Mustafa Çağatay Büyükuysal 000000019810 5633, Zehra Safi Öz 0000000313595026

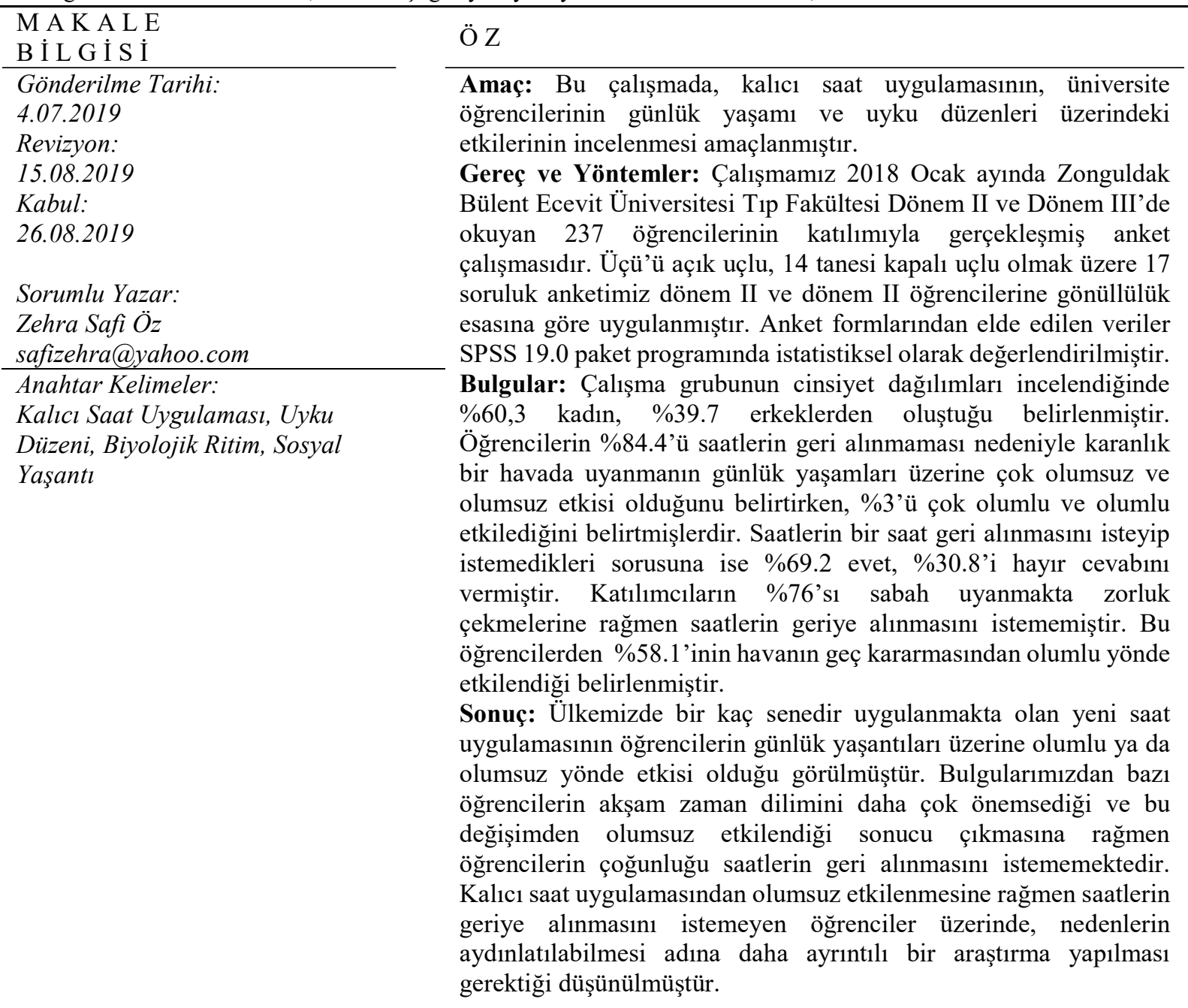




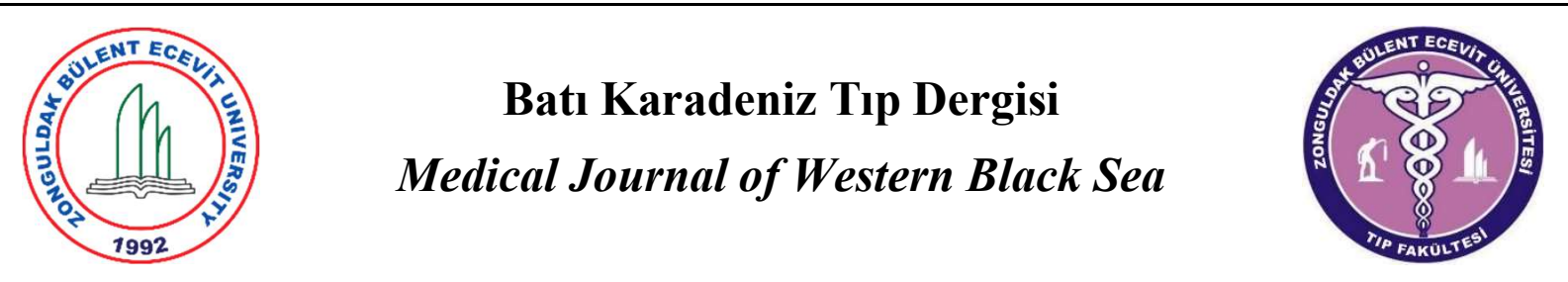

Research Article

Doi: $10.29058 / \mathrm{mjwbs} .2019 .2 .1$

\section{The Effects of The Daylight Saving Time on The Quality of The Daily Life And Sleep of University Students}

Hazal Kardelen Kahraman a , Gaye Atmaca a , Güliz Gülün ${ }^{\text {a }}$, Hasbiye Çalişkan ${ }^{\mathrm{a}}$, İpek Örenbaş a , İrem Tokel $^{\text {a }}$, Melike Saridoğan ${ }^{\text {a }}$, Mustafa Çağatay Büyükuysal ${ }^{b}$, Zehra Safi Öz ${ }^{c}$

${ }^{a}$ Zonguldak Bulent Ecevit University School of Medicine Fourth Grade Students, Zonguldak, Turkey.

${ }^{b}$ Zonguldak Bulent Ecevit University School of Medicine, Department of Biostatistics, Zonguldak, Turkey.

${ }^{\mathrm{c}}$ Zonguldak Bulent Ecevit University School of Medicine, Department of Medical Biology, Zonguldak, Turkey.

\begin{tabular}{l} 
A R T I C L E \\
I N F O R M A T I O N \\
\hline Date of Submission \\
4.07 .2019 \\
Revision: \\
15.08.2019 \\
Accepted: \\
26.08.2019 \\
Correspondence Author: \\
Zehra Safi Öz \\
safizehra@yahoo.com \\
\hline Key Words: \\
Daylight Saving Time, Sleep \\
Pattern, Biological Rhythm, Social \\
Experience
\end{tabular}

\section{A B S T R A C T}

Aim: The aim of this study was to investigate the effects of the daylight saving time on the quality of the sleep/ daily life of university students.

Material and Methods: This study was conducted with the participation of 237 students studying in Zonguldak Bülent Ecevit University Medical Faculty, Term II and Term II in January 2018. Our questionnaire consisting of 17 questions including three open ended, 14 closed-ended, was applied to the students of term II and term III on a voluntary basis. The data obtained from the questionnaire forms are included in the SPSS 19.0 package program.

Results: When the gender distribution of the study group was examined, it was determined that $60.3 \%$ of the women and $39.7 \%$ of the men. $84.4 \%$ of the students stated that waking up in the dark weather had a very negative and negative impact on their daily life because they did not get the hours back, while $3 \%$ said it had a very positive and positive effect. The question of whether they want the hours to be taken back by an hour, $69.2 \%$ yes, $30.8 \%$ of the answer is no. $76 \%$ of the participants who had difficulty in waking up in the morning did not want the hours to be taken back. When these students are affected by the late darkening of the evening air, it is seen that $58.1 \%$ of them give a positive answer.

Conclusion: It has been observed that the new clock application, which has been applied in our country for several years, has a positive or negative effect on the daily life of the students. It can be concluded that some of our students give more importance to the evening time zone, but it is thought that a more detailed research should be done on the students who do not want the hours to be taken back even though they are negatively affected by both situations. 


\section{Giriş}

Zaman, insanların ortak hareket etmelerini ve anlaşmalarını sağlayan önemli bir kavramdır. İşlerin planlanabilmesi ve belirli bir zaman çerçevesinde yapılabilmesi içinse saat kullanılmaktadır. Güneşin doğuş ve batış saatlerinin mevsimlere göre değişiklik göstermesinden dolayı dünyanın birçok ülkesinde yaz ve kış saat uygulaması yapılmaktadır (1).

Güneş 1şı̆̆ sirkadiyen ritmin oluşumunda rol alan en güçlü uyarandır (2). Sirkadiyen ritim; dünyanın kendi ekseni etrafında yaklaşık 24 saat süren dönüşünün canlılar üzerinde oluşturduğu biyokimyasal, fizyolojik ve davranışsal ritimlerin tekrar edilmesi olarak tanımlanmaktadır (3). Sirkadiyen ritim, circa ve diem sözcüklerinin birleşmesi ile oluşur ve "biyolojik saat" olarak da adlandırılır. $\mathrm{Bu}$ saat aynı zamanda organizmanın çevreye uyumuna ve uyku-uyanıklık düzeninin ayarlanmasında yardımcıdır (4).

Uyku, eş zamanlı olarak gelişen bir dizi fizyolojik olay sonucunda oluşur. Bireyi, yaşam kalitesini ve iyilik durumunu etkileyen önemli bir değişken olup insan sağlığı, sosyal yaşam ve de öğrencilerin eğitim başarısı üzerinde etkili bir kavramdir. Bu nedenle uykunun kalitesi, uykuda geçirilen süre ve uyku düzeni bireyin sağlığ üzerinde önemli rol oynamaktadır $(5,6,7)$. Uykuuyanıklık siklusu; biyolojik ritme bağlı olarak oluşur. 24 saat süren evrelerin tekrarlaması ile oluşan sirkadiyen ritm bu siklus üzerinde belirleyicidir. Sirkadiyen ritmin oluşumunda rol alan en güçlü uyaran güneş 1şı̆̆ıdır. Iş̧k uyaranlarının suprakiyazmatik nükleusu etkilemesi retinal fotoreseptörler aracılığı ile sağlanır. Bu uyaranlara bağlı olarak oluşan bir diğer işlev ise melatonin sentezidir. Melatonin salgılanması karanlıkta en yüksek düzeye ulaşarak bu nükleusun aktivitesini düzenler $(2,8)$.

Uyku süresi ve kalitesi ile ilgili olarak Üniversite öğrencileri ile yapılan bazı çalışmalarda öğrencilerinin yetersiz uyuduğu ve çoğunluğun uyku kalitesinin kötü olduğu belirtilmiştir $(9,10)$. Öğrencilerin uyku düzenleri birçok farklı değişkenden etkilenmektedir. Aysan ve ark. 2014 yılında yaptıkları çalışmalarında öğrencilerin uyku kalitesinin yaş, cinsiyet, okuduğu bölüm, kaldığı yer gibi pek çok faktörden etkilendiğini belirtmişlerdir (10). Gerek uyku düzeni üzerindeki kalıcı saat uygulaması etkisine ilişkin sınırlı sayıda araştırma bulunması gerekse Nobel ödüllü Türk Bilim insanı Aziz Sancar'ın sirkadiyen ritm ile DNA onarımı, kanser ve kemoterapi ile ilişkisini açıklamaya yönelik çalışmaları 1şı̆̆ında bu çalışmamızda kalıcı saat uygulamasının, üniversite öğrencilerinin günlük yaşamı ve uyku düzenleri üzerindeki etkilerinin değerlendirilmesi amaçlanmıştır.

\section{Gereç ve Yöntemler}

Çalışmamız Ocak 2018 tarihinde Zonguldak Bülent Ecevit Üniversitesi Tıp Fakültesi Dönem II ve Dönem III'de okuyan 237 öğrencinin katılımıyla gerçekleşmiş anket çalışması olup üçü'ü açık uçlu, 14 tanesi kapalı uçlu olmak üzere 17 sorudan oluşmaktadır. Anketimizde yer alan sorular Tablo 1 'de sunulmuştur. Araştırma Zonguldak Bülent Ecevit Üniversitesi İnsan Araştırmaları Etik Kurulu tarafindan 31.01.2018.tarihinde onay almıştır (No: 309).

Araștırmada, anket formlarından elde edilen veriler SPSS 19.0 paket programına kaydedildi ve istatistiksel olarak değerlendirildi. Çalışmada yer alan nitel değişkenlere ait tanımlayıcı istatistikler frekans ve yüzde ile; nicel değişkenler medyan, minimum,maksimum, aritmetik ortalama ve std. sapma değerleriyle gösterildi. Nitel değişkenlerin gruplar arası karşılaştırmalarında Pearson, Yates ve Fisher-Freeman-Halton ki-kare testi kullanılmıştır. Sürekli değişkenlerin normal dağılıma uygunluğu Shapiro Wilk testi ile incelendi. Normal dağılım göstermeyen değişkenlerin iki grup karşılaştırmalarında Mann Whitney U testi kullanıldı. Çalışmadaki tüm istatistiksel analizlerde p değeri 0,05'in altındaki sonuçlar istatistiksel olarak anlamlı kabul edildi. 
Tablo 1. Çalışmada kullanılan anket formu örneği

Açıklama: ZBEÜ Tıp Fakültesi Dönem 2 ve 3 öğrencilerinden oluşan çalışma grubu tarafundan gerçekleştirilen bu anket çalışmasında saatlerin geriye alınmamasının üniversitemiz öğrencileri üzerindeki etkilerinin incelenerek sonuçların ortaya konması amaçlanmaktadır. Anketimize katılım gönüllülük esasına dayalı olup, katılımcı sayısının yüksek olmasının anket sonuçlarının daha güvenilir olmasını sağlayacaktır. Bu nedenle anketimize katılım göstermeniz araştırmamızın sağlığı ve güvenilirliği açısından önem taşımaktadır.

\section{KALICI SAAT UYGULAMASININ ÜNIVERSITE ÖĞRENCİLERININN GÜNLÜK YAŞANTISINA ETKILERININ INCELENMESI \\ ANKET FORMU}

(Dikkat: Seçenekli sorularda size uygun şıkkı yuvarlak içine alınız)

\begin{tabular}{l|l} 
1-Cinsiyetiniz: & 1. Kadın \\
& 2. Erkek
\end{tabular}

2-Kaç yaşındasınız?

3-Hafta içi ortalama kaç saat uyuyorsunuz?

4-Hafta içi sabah uyanmakta zorlanıyor musunuz?

..........

5-Hafta içi sabah 1 saat daha geç kalksanız daha dinlenmiş hisseder misiniz?

6-Hafta sonu sabah ortalama saat kaçta uyaniyorsunuz?

7-Hafta sonu sabah uyanmakta zorlanyor musunuz?

8-Saatlerin geriye alınmaması nedeniyle karanlık bir havada uyanmak günlük yaşamınızı hangi düzeyde etkiliyor?

1. Evet (Soru 5'den devam ediniz)

2. Hayır (Soru 6'dan devam ediniz)

1. Evet

2. Hayır

1. Evet

2. Hayır

1.Çok olumsuz etkiliyor

2.Olumsuz etkiliyor

3.Etkilemiyor

4.Olumlu etkiliyor

5.Çok olumlu etkiliyor

9-Sabah derslerine katılımınız 15 Ekim'den itibaren hangi yönde değişti?

1.Çoğunlukla sabah derslerine uyanamadığım için katılamıyorum(Soru 10'dan devam ediniz)

2.Bazen sabah derslerine uyanamadığım için katılamıyorum(Soru 10'dan devam ediniz)

3.Genellikle sabah derslerine katıliyorum(Soru 11 'den devam ediniz)

4.Sabah derslerine katılmakta herhangi bir sorun yaşamıyorum. (Soru 11'den devam ediniz)

10-Sabah uyanamadığınız için katılamadığınız

1. Evet

2. Hayır olduğunu düşünüyor musunuz?

11-Hafta içi akşamları ders çıkışı havanın bir saat daha geç kararması sizi nasıl etkiliyor?

1. Çok olumlu

2. Olumlu

3.Etkilemiyor

4.Olumsuz

5.Çok olumsuz

12-Saatlerin geri alınmaması sosyal aktivitelere (spor, sinema, tiyatro vb.) katılma sıklığımı etkiliyor.

1.Hiç katılmıyorum

2.Katılmiyorum

3.Kararsizim

4.Katıliyorum

5.Tamamen katıliyorum

13-Hafta içi akşamları ders çıkışı havanın daha aydınlık olması sosyal aktivitelere ayırdığınız zamanı hangi yönde etkiliyor?

1.Sosyal aktivitelere ayıracak daha çok zamanım oluyor (Soru 14'e geçiniz)

2. Etkilemiyor (Soru 15'e geçiniz)

3.Sosyal aktivitelere ayıracak daha az zamanım oluyor (Soru 15'e geçiniz) 


\begin{tabular}{|l|l|}
\hline $\begin{array}{l}\text { 14-Sosyal aktivitelere ayıracak daha çok zamanınızın } \\
\text { olması ruh halinizi hangi yönde etkiliyor? }\end{array}$ & $\begin{array}{l}\text { 1. Çok olumlu } \\
\text { 2. Olumlu } \\
\text { 3.Etkilemiyor } \\
\text { 4.Olumsuz } \\
\text { 5.Çok olumsuz }\end{array}$ \\
\hline $\begin{array}{l}\mathbf{1 5 - K ı s ̧ ı n ~ h a v a n ı n ~ e r k e n ~ k a r a r m a s ı ~ u y k u ~ s a a t i n i z i ~} \\
\text { nasıl etkiliyor? }\end{array}$ & $\begin{array}{l}\text { 1.Daha çok uyuyorum } \\
\text { 2.Etkilemiyor } \\
\text { 3.Daha az uyuyorum }\end{array}$ \\
\hline $\begin{array}{l}\mathbf{1 6 - K ı s ̧ ı n ~ h a v a n ı n ~ e r k e n ~ k a r a r m a s ı ~ d e r s ~ c ̧ a l ı s ̧ m a y a ~} \\
\text { ayırdığınız vakti hangi yönde etkiliyor? }\end{array}$ & $\begin{array}{l}\text { 1.Daha çok çalışıorum } \\
\text { 2.Etkilemiyor } \\
\text { 3.Daha az çalışıyorum }\end{array}$ \\
\hline $\mathbf{1 7 - S a a t l e r i n ~} \mathbf{1}$ saat geriye alınmasını ister misiniz? & $\begin{array}{l}\text { 1. Evet } \\
\text { 2. Hayır }\end{array}$ \\
\hline Anketimize katılımınızdan dolayı çok teşekkür eder, iyi günler dileriz. \\
\hline
\end{tabular}

\section{Bulgular}

Çalışmada elden edilen veriler ışı̆̆ında çalışma grubunun cinsiyet dağılımları incelendiğinde \%60,3'ünün kadın, \%39.7'sinin erkeklerden oluştuğu belirlenmiştir. Yaş ortalaması ise $21.0 \pm 1,3$ dür (Tablo 2).

Tablo 2. Demografik özellikler

\begin{tabular}{|c|c|}
\hline Demografi & $\begin{array}{l}\text { Çalışma } \\
\text { grubu }\end{array}$ \\
\hline $\begin{array}{l}\text { Cinsiyet } \\
\text { Kadın [n(\%)] } \\
\text { Erkek [n(\%)] }\end{array}$ & $\begin{array}{c}143(60,3) \\
94(39,7)\end{array}$ \\
\hline $\begin{array}{l}\text { Ortalama } \pm \\
\text { Standart sapma } \\
\text { Minimum-Maksimum }\end{array}$ & $\begin{array}{c}21 \pm 1,3 \\
18-26\end{array}$ \\
\hline
\end{tabular}

Hafta içi ve hafta sonu uyku sürelerinin saatlerin geriye alınmasını isteyip istememeye göre karşılaştırılması ise Tablo 3'de sunulmuştur. Saatlerin geriye alınmasını isteyenlerle istemeyenler arasında hafta içi ortalama uyku süresi bakımından istatistiksel olarak anlaml 1 bir farkl111k bulunmamıștır $(p=0,290)$. Öğrenciler saatlerin geriye alınmasını isteyenlerle istemeyenler arasında hafta sonu ortalama uyku süresi bakımından da istatistiksel olarak anlamlı farklılık yoktur $(\mathrm{p}=0,721)$.

Saatlerin geriye alınmasının öğrencilerin günlük yaşamlarına ve uyku düzenlerine etkilerinin sorgulandığı bu çalışmada, 'Saatlerin geriye alınmaması nedeniyle karanlık bir havada uyanmak günlük yaşamınızı hangi düzeyde etkiliyor?' sorusuna \%38'i çok olumsuz etkiliyor bu nedenle saatlerin 1 saat geriye alınmasını isterim yanıtını verirken \%2.4'ü çok olumlu etkiliyor yanıtını vermiştir $(\mathrm{p}<0.001)$ (Tablo 4, Grafik 1).

'Sabah derslerine katılımınız 15 Ekim' den itibaren hangi yönde değişti?' sorusuna ise çoğunlukla sabah derslerin uyanamadığım için olumsuz etkilendi, bu nedenle saatlerin 1 saat geri alınmasını isterim diyenlerin sayısı 36 (\%22.0) kişidir. 25 kişi (\%15.2) ise sabah derslerine katılmakta herhangi bir sorun yaşamadığını belirtmiştir ( $\mathrm{p}=0,009)$ (Tablo 4 , Grafik 2). 'Saatlerin geri alınmaması sosyal aktivitelere (spor, sinema, tiyatro vb.) katılma siklığımı etkilemiyor' diyen öğrencilerin \%6.6's1 saatlerin 1 saat geri alınmasını isterim yanıtını verirken, tamamen kat1liyorum diyenlerin oranı \%11.4'tür $(\mathrm{p}=0,012)$ (Tablo 4, Grafik 3). 'Kışın havanın erken kararması ders çalışmaya ayırdığınız vakti hangi yönde etkiliyor?' sorusuna öğrencilerin \%16.3'ü daha çok ders çalışıyorum ancak yine de saatlerin 1 saat geri alınmasını isterim şeklinde cevaplamıştır. Daha az çalışıyorum diyenlerin oranı ise $\% 44.0$ olarak gözlenmiştir $(p=0,027)$. 'Hafta içi akşamları ders çıkışı havanın bir saat daha geç kararması sizi nasıl etkiliyor?' ve 'Kışın havanın erken kararması uyku saatinizi nasıl etkiliyor?' sorularına verilen yanıtlarda ise saatlerin 1 saat geriye alınmasını isteyenler ile istemeyen öğrenciler arasındaki fark anlamlı bulunmamışıtır ( $\mathrm{p}>0.05)$. 
Tablo 3. Hafta içi ve hafta sonu uyku sürelerinin saatlerin geriye alınmasını isteyip istememeye göre karşılaştırılması

\begin{tabular}{|c|c|c|c|}
\hline & \multicolumn{2}{|c|}{ Saatlerin geri alınmasını istiyor musunuz } & \multirow[b]{2}{*}{$\mathbf{p}$} \\
\hline & Evet & Hayır & \\
\hline Hafta içi ortalama uyku süresi & $7(4-12)$ & $7(4-10)$ & 0,290 \\
\hline Hafta sonu ortalama uyku süresi & $9(4-15)$ & $9(5-12)$ & 0,721 \\
\hline
\end{tabular}

Tablo 4. 17. soru ile $8,9,11,12,15$ ve 16 . soruların birlikte değerlendirilmesi

\begin{tabular}{|c|c|c|c|c|}
\hline & \multicolumn{2}{|c|}{$\begin{array}{l}\text { Soru 17. Saatlerin } 1 \text { saat } \\
\text { geriye alınmasını } \\
\text { mister } \\
\text { miniz? }\end{array}$} & \multirow[t]{2}{*}{$\mathbf{p}$} \\
\hline & & Evet & Hayır & \\
\hline \multirow{5}{*}{$\begin{array}{l}\text { Soru 8. Saatlerin geriye alınmaması } \\
\text { nedeniyle karanlık bir havada uyanmak } \\
\text { günlük yaşamınızı hangi düzeyde } \\
\text { etkiliyor? }\end{array}$} & Çok olumsuz etkiliyor & $63(\% 38,0)$ & $12(\% 16,2)$ & \multirow[t]{5}{*}{$\mathbf{0 , 0 0 1}$} \\
\hline & Olumsuz etkiliyor & $77(\% 46,4)$ & $19(\% 25,7)$ & \\
\hline & Etkilemiyor & $21(\% 12,7)$ & $34(\% 45,9)$ & \\
\hline & Olumlu etkiliyor & $1(\% 0,6)$ & $4(\% 5,4)$ & \\
\hline & Çok olumlu etkiliyor & $4(\% 2,4)$ & $5(\% 6,8)$ & \\
\hline \multirow[t]{4}{*}{$\begin{array}{l}\text { Soru 9. Sabah derslerine katılımınız } 15 \\
\text { Ekim' den itibaren hangi yönde değişti? }\end{array}$} & $\begin{array}{l}\text { Çoğunlukla sabah derslerin } \\
\text { uyanamadı̆̆ım için }\end{array}$ & $36(\% 22,0)$ & $9(\% 12,2)$ & \multirow[t]{4}{*}{0,009} \\
\hline & $\begin{array}{l}\text { Bazen sabah derslerin } \\
\text { uyanamadı̆ı̆m için }\end{array}$ & $61(\% 37,2)$ & $21(\% 28,4)$ & \\
\hline & $\begin{array}{l}\text { Genellikle sabah derslerine } \\
\text { katılıyorum }\end{array}$ & $42(\% 25,6)$ & $27(\% 36,5)$ & \\
\hline & $\begin{array}{l}\text { Sabah derslerine } \\
\text { katılmakta herhangi bir } \\
\text { sorun yaşamiyorum }\end{array}$ & $25(\% 15,2)$ & $17(\% 23,0)$ & \\
\hline \multirow{5}{*}{$\begin{array}{l}\text { Soru 11. Hafta içi akşamları ders çıkışı } \\
\text { havanın bir saat daha geç kararması sizi } \\
\text { nasıl etkiliyor? }\end{array}$} & Çok olumsuz etkiliyor & $18(\% 11,0)$ & $11(\% 14,9)$ & \multirow[t]{5}{*}{0,156} \\
\hline & Olumsuz etkiliyor & $50(\% 30,5)$ & $32(\% 43,2)$ & \\
\hline & Etkilemiyor & $58(\% 35,4)$ & $17(\% 23,0)$ & \\
\hline & Olumlu etkiliyor & $29(\% 17,7)$ & $9(\% 12,2)$ & \\
\hline & Çok olumlu etkiliyor & $9(\% 5,5)$ & $5(\% 6,8)$ & \\
\hline \multirow{5}{*}{$\begin{array}{l}\text { Soru 12. Saatlerin geri alınmaması } \\
\text { sosyal aktivitelere (spor, sinema, tiyatro } \\
\text { vb.) katılma sıklığımı etkiliyor. }\end{array}$} & Hiç katılmıyorum & $11(\% 6,6)$ & $12(\% 16,2)$ & \multirow[t]{5}{*}{$\mathbf{0 , 0 1 2}$} \\
\hline & Katılmiyorum & $29(\% 17,5)$ & $22(\% 29,7)$ & \\
\hline & Kararsızım & $65(\% 39,2)$ & $23(\% 31,1)$ & \\
\hline & Katıliyorum & $42(\% 25,3)$ & $10(\% 13,5)$ & \\
\hline & Tamamen katıliyorum & $19(\% 11,4)$ & $7(\% 9,5)$ & \\
\hline \multirow{3}{*}{$\begin{array}{l}\text { Soru } 15 \text {. Kışın havanın erken kararması } \\
\text { uyku saatinizi nasıl etkiliyor? }\end{array}$} & Daha çok uyuyorum & $69(\% 41,6)$ & $23(\% 31,1)$ & \multirow[t]{3}{*}{0,095} \\
\hline & Etkilemiyor & $76(\% 45,8)$ & $45(\% 60,8)$ & \\
\hline & Daha az uyuyorum & $21(\% 12,7)$ & $6(\% 8,1)$ & \\
\hline \multirow{3}{*}{$\begin{array}{l}\text { Soru } 16 . \text { Kışın havanın erken kararması } \\
\text { ders çalışmaya ayırdığınız vakti hangi } \\
\text { yönde etkiliyor? }\end{array}$} & Daha çok çalışıyorum & $27(\% 16,3)$ & $16(\% 21,6)$ & \multirow[t]{3}{*}{$\mathbf{0 , 0 2 7}$} \\
\hline & Etkilemiyor & $66(\% 39,8)$ & $39(\% 52,7)$ & \\
\hline & Daha az çalışıyorum & $73(\% 44,0)$ & $19(\% 25,7)$ & \\
\hline
\end{tabular}




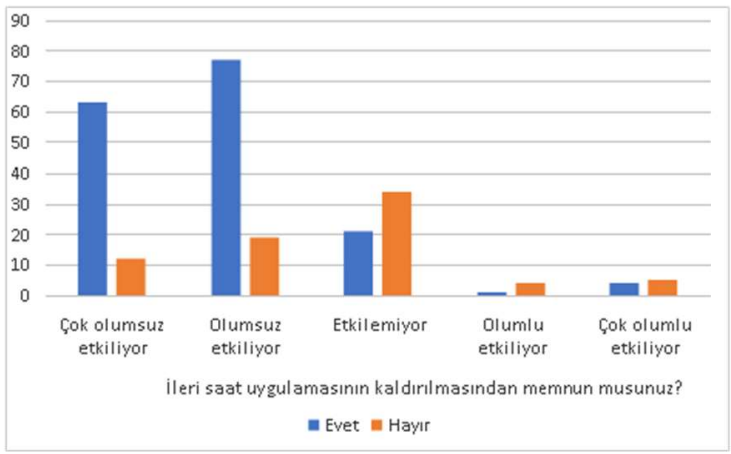

Grafik 1. Saatlerin geriye alınmaması nedeniyle karanlık bir havada uyanmak günlük yaşamınızı hangi düzeyde etkiliyor? (Soru 8)

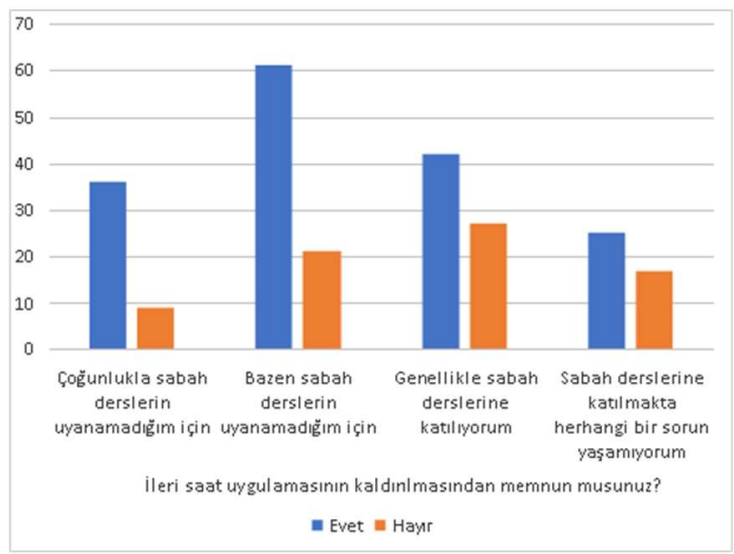

Grafik 2. Sabah derslerine katılımınız 15 Ekim'den itibaren hangi yönde değişti? (Soru 9)

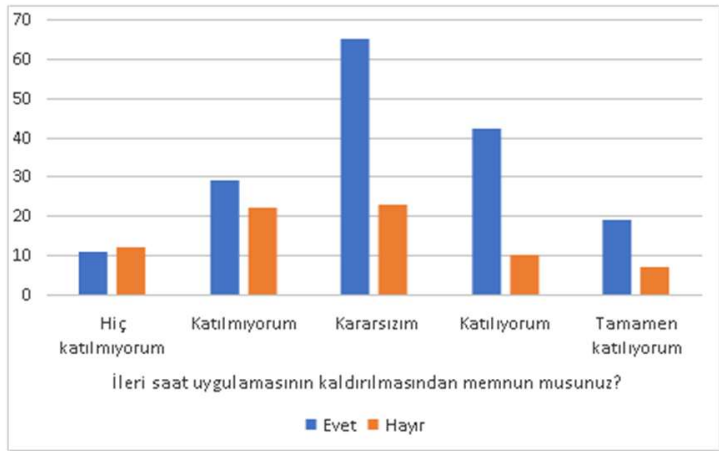

Grafik 3. Saatlerin geri alınmaması sosyal aktivitelere (spor, sinema, tiyatro vb.) katılma sıklığını etkiliyor mu? (Soru 12)

\section{Tartışma}

Uyku; genç bireylerin gelişiminde ve sağlığında önemli yer tutar. Bireyi, yaşam kalitesini ve iyilik durumunu etkileyen önemli bir değişkendir. Öğrencilerin günlük yaşantıları ve uyku düzenleri birçok farklı parametre ile ilişkilidir. $\mathrm{Bu}$ parametrelerden birinin de yeni saat uygulaması olduğunu düşüncesi ile çalışmamızda kalıcı saat uygulamasının, üniversite öğrencilerinin günlük yaşamı ve uyku düzenleri üzerindeki etkileri değerlendirilmiştir. Yaz saati, zaman ve enerji tasarrufu amacıyla bir bölgede gün ışı̆̆ından daha çok yararlanmak üzere saatin belirli ölçüde değiştirilmesi uygulamasıdır. Her yıl uygulanan ve hayatımızda önemli bir değişiklik oluşturan yaz ve kış saati uygulamasında son yıllarda herhangi bir düzenleme yapılmamaktadır.

Günümüze değin uyku süresi ve kalitesi ile ilgili pek çok çalışma yapılmıştır. Orzech ve arkadaşlarının yapmış oldukları çalışmalarında, üniversite öğrencilerinin yetersiz uyuduğu sonucuna varılmıştır (11). Tonetti ve arkadaşlarının 2013 yılında yaptıkları çalışmalarında da kalıcı yaz saati uygulamasının uyku düzenini etkilediği bildirilmiştir (12). Mayda ve arkadaşlarının (2012) tıp fakültesi öğrencilerinde uyku kalitesini inceledikleri araştırmalarında, öğrencilerin yarısından fazlasının uyku kalitesinin kötü olduğu görülmüştür (9). Saygılı, Akıncı, Arıkan ve Dereli (2011) nin çalışmaları da bu bulguyu destekler niteliktedir (13). Ayrıca uykusuzluğun öğrencilerin akademik başarısını olumsuz yönde etkilediği de Curcio ve arkadaşlarının çalışmalarında bildirilmiştir (14). Yetersiz uyku sağlık için tehdit oluşturmasının yanısıra bilişsel, psikomotor ve duygusal fonksiyonlarda azalmaya neden olur $(11,15)$.

Çalışmamızda öğrencilerin uyku verimliliği göz önünde bulundurulmuştur. Çalışma grubunun cinsiyet dağılımları incelendiğinde \%60,3 kadın, \%39.7 erkeklerden oluştuğu belirlenmiştir. Öğrencilerin \%84.4'ü saatlerin geri alınmaması nedeniyle karanlık bir havada uyanmanın günlük yaşamları üzerine çok olumsuz ve olumsuz etkisi olduğunu belirtirken, \% 3'ü çok olumlu ve olumlu etkilediğini bildirmişlerdir. Saatlerin bir saat geri alınmasını isteyip istemedikleri sorusuna ise \%69. 2 evet, \%30.8'i hayır cevabını vermiştir. Sabah uyanmakta zorlanan katılımciların \%76'sı buna rağmen saatlerin geriye alınmasını istememiştir. $\mathrm{Bu}$ öğrencilerden \%58.1'inin havanın geç kararmasından olumlu yönde etkilendiği belirlenmiştir. Katılımcıların \%36.7'si akşam havanın daha geç kararmasının sosyal aktivitelere katılımını etkilediğini düşünürken, \%23'ü bu düşünceye katılmamıştır. Cinsiyet olarak bakıldığında da kadın ve erkek öğrenciler arasında havanın geç kararmasından etkilenmeye dair anlamlı bir fark görülmemektedir. Sabah uyanmakta zorlanan katılımcıların \%76'sı buna rağmen saatlerin geriye alınmasını istemezken, bu kişilerin akşam havanın geç kararmasından uyanmakta zorlanmalarına nasıl etkilendiklerine bakıldığında 
\%58.1'inin olumlu cevabını verdiği görülmektedir. Aradaki farktan bazı öğrencilerin akşam zaman dilimini daha çok önemsediği çıkarımı yapılabilmekte ancak iki durumdan da olumsuz etkilenmesine rağmen saatlerin geriye alınmasını istemeyen öğrencilerin neden istemediklerine ilişkin faktörlerin aydınlatılmasına ilişkin daha geniş katılımlı detaylı çalışmalara ihtiyaç olduğu düşünülmektedir.

Özellikle topluma sağlık hizmeti veren hekimlerin fiziksel ve ruhsal olarak iyilik halinde bulunmaları ve bu durumu sürdürmeleri önemlidir. Bunun için sağlıklı yaşam tarzının parametreleri arasında yer alan yeterli ve kaliteli uykunun ve de günlük yaşamın sağlıklı olarak idamesinin sağlanması için gerekli şartların ve bunları etkileyen faktörlerin detaylandırılmasının yararlı olacağı kanaatindeyiz.

\section{Kaynaklar}

1. Kocalar A.O., Toros H. Yaz ve Kış Saati Uygulamasının Türkiye için Değerlendirilmesi. Avrupa Bilim ve Teknoloji Dergisi. 2014;1(3):59.

2. Şahin L. ve Aşcioğlu M. Uyku ve uykunun düzenlenmesi. Sağlık Bilimleri Dergisi. 2013;22(1): 93-98.

3. Sözlü S. ve Şanlıer N. Sirkadiyen ritm, sağlık ve beslenme İlişkisi. Turkiye Klinikleri J Health Sci. 2017;2(2):100-9

4. Özbayer C. ve Değirmenci İ. Sirkadiyen saat, hücre döngüsü ve kanser. Dicle Tıp Dergisi. 2011; 38 (4): 514-518

5. Engin E. ve Özgür G. Yoğun bakım hemşirelerinin uyku düzen özelliklerinin iş doyumu ile ilişkisi. Ege Üniversitesi Hemşirelik Yüksekokulu Dergisi, 2004;20 (2):45-55.

6. Chaudhary BA et al, Blanchard AR. Sleepmechanics. In: Collop NA, Phillips BA (Eds). Sleep Medicine. 2002; 1-11.
7. Mc. Commirck DA. Neurotransmitteractions in the thalamus and cerebral cortex and their role in neuromodulation of thalamocorticalactivity. ProgNeurobiol. 1992; 39: 337-388.

8. Akıncı E, Orhan F.Ö. Sirkadiyen Ritim Uyku Bozuklukları. Psikiyatride Güncel YaklaşımlarCurrent Approaches in Psychiatry. 2016; 8(2):178189

9. Mayda A. S. ve ark. 4-5-6. Sınıf tıp fakültesi öğrencilerinde uyku bozukluğu sıklığı. Düzce Üniversitesi Sağlık Bilimleri Enstitüsü Dergisi, 2012;2 (2): 8-11.

10. Aysan E. ve ark. Üniversite Öğrencilerinde Uyku Kalitesi ve Etkileyen FaktörlerDokuz Eylül Üniversitesi Hemşirelik Yüksekokulu Elektronik Dergisi. 2014;7(3):193-198

11. Orzech K.M., Salafsky D.B. and HamiltonnL.A. The State of Sleep among College Students at a Large Public University. Journal of American College Health. 2011;59: 612-619.

12. Tonetti L. et all. Effects of Transitions into and out of Daylight Saving Time on the Quality of the Sleep/Wake Cycle: an Actigraphic Study in Healthy University Students. Chronobiology International. 2013; 30(10): 1218-1222

13. Sayg1lı S. ve ark. Üniversite Öğrencilerinde Uyku Kalitesi Ve Yorgunluk. Electronic Journal of Vocational Colleges. 2011:1(1):88-94

14. Curcio G., Ferrara M., and Gennaro L. Sleeploss, learning capacity and academic performance. SleepMed Rev, 2006;10: 323-337.

15. Abdulkadiroğlu Z., Bayramoğlu F. ve İlhan N. Uyku ve uyku bozuklukları. Genel Tıp Dergisi, 1997;7 (3): 161-166 